\title{
RELATION OF NON EXECUTIVE DIRECTORS AND OWNERSHIP CONCENTRATION WITH DISCRETIONARY ACCRUAL ACCOUNTING
}

\author{
Mohammadreza Abdoli \\ Department of Accounting, Shahrood Branch, \\ Islamic Azad University, Shahrood, Iran \\ Email:mra830@yahoo.com
}

\begin{abstract}
In this study we consider the relationship and the effect of performance of non executive directors and ownership concentration on earnings manipulation by company's managers. On the basis of governance rule and also Iran business rule, the companies in Tehran stock exchange should abide about the combination of the board and also interrelated committee and protect minority stockholders against majority. In order to do this research, the information of the companies in financial statements and the reports of the Tehran stock exchange have been used. For the measurements of the earnings smoothing John's adjusted model has been used and for the measurement of the concentration of company's ownership "Herfindal" and "Hireshman" has been used. The choice of the companies is randomly and the confidence interval has been considered \%95. For research, observe 435 corporation- year and time period is 2005 - 2010. The results of the research reveal don't meaningful relationship of non executive directors and discretionary accrual accounting and the relationship is a positive. In companies which the concentration of ownership is high, management and earnings manipulation is also high and has a meaningful relationship and negative with these variables. The segregation of the companies into government and private causes to different the results. In private companies the concentration of the ownership is little and the statistical mean of discretionary accrual accounting items is low and non executive directors ratio is low but in governmental corporations statistical mean of discretionary accrual accounting item is high and ratio of corporations that has internal auditing is high to private corporations. Further more almost of non executive directors in Iranian corporation have nonfinancial technique and knowledge and ratio of them in board corporation is higher than executive directors.
\end{abstract}

Keywords: discretionary accrual accounting , non executive director, ownership concentration

\section{INTRODUCTION}

In transition economies, like china ,the primary governance mechanism is the state and informal networks (shen and lin 2009).In India , business groups provide accountability, especially in the larger firm (Zattoni and Pederson and Kumar 2009). Notably ,Islamic nations primarily rely on Sharia law to curband guide business decisions(Safieddine 2009)(Richard and Skiner and Allen 2008, 2009) and (thaghfi 2009) and( Baharmoghadam 2010) and (Shiper 1984) and (Chodhari 2007) believe that the managers may embark with a set of real financial events to manipulate the in registering the public costs and advertisement and discounts and administrative costs also the coagulation of contracts which causes the deviance of clients from financial statements.

In the face of the divergence between sacred and secular in the west. Islam has always been viewed as the blueprint and social cement of a civilization. They explore alternative perspectives on governance by comparing the Islamic model of governance with the conventional western model. Within this framework, they present the principles of Islamic economies and Justice and review the practices of taxation, budget deficits ,and government finance. This methodology selects the theories that are closest to the Islamic spirit.

(Richard and Skiner and Allen 2008, 2009) and (thaghfi 2009) and( Bahar Moghadam 2010) and (Shiper 1984) and (Chodhari 2007) believe that the managers may embark with a set of real financial events to manipulate the profits. Such cases we can refer to changing the sales program, costs of research and development and tardiness in registering the public costs and advertisement and discounts and administrative costs also the coagulation of contracts which causes the deviance of clients from financial statements.

A numerous research have shown (joong and others 2009, vliasani and others 2006) that in companies is which the ownership distribution is more than others and there is no stockholders or on the other hand the stockholders are distributed. The possibility of controlling over the managers performance is less than others. 
Some researcher in different countries has emphasized this subject that the companies whose board members are non-duty-board and more experienced and skillful in the company's subject field, can have a good control over the executive managers and managing director performance.

And reduce the agencies, costs, moreover if the managing director's duty is separated from the board in the company. Controlling over the managing director performance will be improved (Hasas Yeganeh 2009-2008 and Abdoli 2010, Aghaie and Chalaki 2007, Mohammad al Abbas 2009).

According to the results of other researchers about the effect of improvement of super in tendency and control over the reduction of the managers agency costs and according to the publication of the corporate governance by Tehran Stock Exchange the present research has been done and is being tried to investigate the corporate governance according to Iran particular circumstances and also accounting standards.

The rest of the study is organized as follows: Section 2 reviews the literature on the relationship between corporate governance practices and corporate decisions, such as those relating to investment, financing, dividends, and cash holdings. Section3 describes the research methodology .Section 4 discusses statistical and descriptive results and hypothesis test results. Section 5 presents the conclusions of this study.

\section{BACKGROUND AND HYPOTHESIS DEVELOPMENT}

(Charles Pynt and Remi Janin 2007) in their own research in French have considered the relationship and existence effect of internal auditor and auditing committee and earnings management.

They have assessed the effect of different dimension of auditing quality such as accountant prestige, the existence of auditing committee and their dependence over management and the profit alteration. The results of their research were that the existence of accountants from 5 auditing famous companies has not caused the earnings management reduction. The existence of auditing committee has caused the earnings management. They express that these results in corporate governance is related to French companies which is different from the U.S.A.

(Mohammad Al Abbas 2007) in his research in Saudi Arabia Market has recompensed to relationship of corporate governance with earnings management. The temporal period of his investigation was 2005 to 2007. For the measurement of in discretionary accrual accounting items of the constituents which have been used in this research. The board combination, their independence, the existence of auditing committee in companies and the sovereignty of board duty form managing director of the companies. He has observed no meaningful relationship between corporate governance contractual and earnings management but realized that there is a negative relationship in companies between the auditing institute sizes and discretionary accrual accounting items.

(Silvia Serijaro and Seyed Harta Otama 2008) in his research in Indonesia considered the relationship of the earnings management method with the companies' ownership structure and the size of the company and corporate governance. They realized that family structure in companies has a relationship with both the importance and the earnings management. They also have not observed and found any relationship between company's size and the existence of holding companies, constitutive investment and corporate governance with earnings management.

(Aghai and Chalaki 2009) in their research have refund to the relationship of constitutive investors and board independence with profit flattening in Iranian companies. They realized that there is a negative meaningful relationship between constitutive ownership and earnings management and also board independence with earnings management. They did not find any relationship between ownership concentration with earnings management.

( Hasas Yeganeh and Madahi 2008) have refund in Iran the different effective factors on placement of the company ownership system. The results of their investigation are the effect of factors such as company's ownership structure and the county legal framework and financial systems of a company.

(Yazdainan 2007) have refund in Tehran Stock Exchange to the relationship of board independence and the existence of internal accountant with profit alteration by managers. The result of their research was if $\mathrm{f}$ the percentage of the constitutive is more than $\% 45$, the earnings management reduces and also there is a meaningful relationship between board independence and the existence of internal auditor. 
(Midri 2006) has refund the effect and the position of landowner structure and distributed and public ownership structure and family ownership structure in Iran economy and has concluded that in Iran stock market like counties China and India against the U.S.A laud owner structure and distributed has had the worst performance.

(Mehrazin and Moroosh and Niko Maram 2008) in their research for the exploration of voluntary undertake items have refund to compare the different models in Iranian companies and ultimately, concluded that Johns' modified model and the modified model with their inflation show a better behavior toward earnings management.

( Abdoli 2010) in his research has refund to the relationship of companies' ownership structure and the existence of whole stockholder and the existence of internal auditor with flattening of artificial earning management. The result of his research is the confirmation of the existence of internal auditor with the reduction of earnings management and also is the confirmation of relationship of whole stockholder with earnings management of artificial earning management in accepted companies in Tehran Stock Exchange.

( Chen and Elder and Hung 2010) examine the incentive and entrenchment effects of controlling shareholders on the association between the investment opportunity set and earnings management in Taiwan . they finds that firms with more investment opportunities are more likely to engage in earnings management and also find incentive effects of controlling shareholders on firms financial reporting behavior in that cash flow rights are negatively associated with absolute abnormal accruals under a growth opportunity setting. Their results further indicate that high- growth firms with a high deviation between cash flow right and control right are more likely to engage in earnings management.

( Hasasyeganeh and Madahi 2008) have studies in Iran about different effective factors on placement of the company ownership system. The results of their investigation are the effect of factors such as company's ownership structure and the country legal framework and financial systems of a company.

According to the above researches' results in Iran and according to the corporate governance performance by accepted companies' in Tehran Stock Exchange, hypothesis have been complied:

Hypothesis 1: there is meaningful and negative relationship between non executive director and discretionary accrual accounting items.

Hypothesis 2: there is meaningful and negative relationship between ownership concentration of companies and discretionary accrual accounting items.

\section{METHODOLOGY}

In this section research, variables have been identified and their way of measurement has been explained and then the experimental research according to theoretical principle and also Iran environmental and legal circumstances arranged.

\section{1-Non executive director ratio}

Iranian companies according to trade Law and corporate governance rule and their article can choose their board of directors from out of the company; these directors can be the managers of other company but on the basis of related law to governmental organization they cannot be the managers of governmental corporation. The names of these boards are disclosed in annual report of corporation to public . Since these directors don't work fulltime in the company aren't informed about the detail performance of corporation but they have independence and can supervise on directors and CEO. But, since they don't play role in the company activities and more independent, supposed to have a better super intendance over the board activities. This ratio is obtained through dividing the numbers of non executive directors by total number of the board of directors.

\section{2-Ownership concentration ratio}

In Iranian companies stockholders usually embark to choose the managers and other stockholders (having little share) don't have any role in choosing the managing directors and managers. From the point of view of theoretical it is confirmed. It is supposed that stockholder must take into view his/her benefits and must not consider other stockholders. Iran owns concentration law has not presented a special quality control mechanism. For the measurement of this variable in each company, own concentration rate is calculated the more this standard, the more the concentration of stockholders.

Own concentration is how is the distribution of allotment between different companies stockholders. The less the stockholders, the more concentrated is own. In this study, in order to calculate the own concentration ratio 
from Herfindal -Hireshman model has been used. The above standard is obtained through total square root of allotment percentage belong to companies' stockholders.

Side by side the standard, own concentration rate is increased and in the situation that total allotment belongs to one person. The most value will be allocated and is calculated for equivalent 10000 units whereas, ownership structure was distributed and all stockholders own equal ratios. The "HHI" has the least value and is calculated for the equivalent of $\mathrm{N} / 1000$.

HHI $=\sum\left(p_{i} / p * 100\right)^{2}$

\section{3- Discretionary accrual accounting}

The discretionary accrual accounting of earning is measured with the help of Jones' modified model. Measuring has been mentioned below. In this model has been attempted to separate the discretionary accrual and un discretionary. The effect of economic condition a business on contractual items for a specific period of time which is known as "event period" with selling and properties and machinery variables and equipments is estimated as follow:

$$
\frac{T A_{i t}}{A_{i t-1}}=\alpha_{1}\left(\frac{1}{A_{i t-1}}\right)+\alpha_{2}\left(\frac{\Delta R E V_{i t}}{A_{i t-1}}\right)+\alpha_{3}\left(\frac{P P E_{i t}}{A_{i t-1}}\right)+\varepsilon_{i t}
$$

$\mathrm{TA}_{\mathrm{it}}$ is the total accrual accounting items, $\mathrm{A}_{\mathrm{it}}$ is total assets, $\mathrm{REV}_{\mathrm{it}}$ is changes of selling income and $\mathrm{PPE}_{\mathrm{it}}$ is changes of properties machinery and equipments. After estimating of parameters of the above model by the help of information of the year 2005 to 2009, each company through implementation of temporal models of in discretionary accrual accounting items as mentioned below estimates for the "estimation period" it means the year 2010.

$$
N D A_{i t}=\alpha_{1}\left(\frac{1}{A_{i t-1}}\right)+\alpha_{2}\left(\frac{\Delta R E V_{i t}-\Delta R E C_{i t}}{A_{i t-1}}\right)+\left(\frac{P P E_{i t}}{A_{i t-1}}\right)
$$

In the last step the discretionary accrual accounting items or the standard of earnings management is calculated as below:

$$
D A_{i t}=\frac{T A_{i t}}{A_{i t-1}}-N D A_{i t}
$$

On the basis of theoretical, the total accrual accounting items is calculated with the below method according to annually financial statements. In this research we calculate the difference between net income and net cash flow from the operation on the basis of Iran accounting standards as total accrual items.

$\mathrm{TA}_{\mathrm{it}}=\mathrm{E}_{\mathrm{it}}-\mathrm{OCF}_{\mathrm{it}}$

In the above formula $\mathrm{E}_{\mathrm{it}}$ reagents the net profit before the tax and $\mathrm{OCF}_{\mathrm{IT}}$ cash flow from the operation and $\mathrm{TA}_{\mathrm{it}}$ reagents the total accrual accounting items in time period of 2010.

\section{4-Research model}

According to theoretical bases and research literature and also other carried out researches in Iran, the relationship between variables will be identified as below:

Research model .

$$
\mathrm{DA}_{\mathrm{it}}=\alpha_{0}-\alpha_{1} * \mathrm{CG}_{\mathrm{it}}+\alpha_{2} \text { Variables Control }+\varepsilon
$$

By dividing the variable of corporate governance to each of favorable components of research which has been pointed in hypothesis, the research model will be compiled as below:

$$
\mathrm{DA}_{\mathrm{it}}=\alpha_{0}-\alpha_{1} * \% \text { Non exe director }-\alpha_{2} * \% \text { Own Conc }+\alpha_{3} * \text { Variable Control }+\varepsilon
$$

\% non exe as the none executive directors or out - board of director ratio and \%own conc as the ownership concentration of the companies and variable control involved the controls variables of research, for example the type of companies ownership ( on the basis of governmental and private ) and companies bankruptcy according to the definition of Iran trade law. 


\section{REGRESSION RESULTS}

For the considering of research models and also the check up the research hypothesis, the accepted companies have been evaluated in Tehran Stock Exchange. The end of their fiscal year should be the end of ESFAND ( December) and should not involve the investment companies and in time period of 2005 to 2010 their data should be available. The number of the companies according to the above condition is 232 which 103 companies from different industries have been chosen randomly.

Table 1: Table of descriptive statistic of the statistical sample corporation

\begin{tabular}{|l|l|l|}
\hline Number of Selected Corporation & Total Number of Corporation & Type of industries \\
\hline 18 & 29 & Mineral corporation \\
\hline 16 & 21 & Food Corporation \\
\hline 26 & 45 & Cement and Tile corporation \\
\hline 36 & 65 & Metal corporation \\
\hline 29 & 45 & Automobile corporation \\
\hline 31 & 41 & Petrochemical corporation \\
\hline 22 & 35 & Pharmacy corporation \\
\hline 178 & 281 & Total \\
\hline
\end{tabular}

Before investigation and checking up each of the research hypothesis the results of descriptive statistic related to each of the variables will be studied. The results of the tests related to regression presumptions are offered and in the end the results of research hypotheses will be displayed. The results of variables are shown in below table:

Table 2: table of descriptive statistic of the variables

\begin{tabular}{|l|l|l|l|l|}
\hline Variance & St. Deviation & Statistical Mean & Type of corporation & Variable \\
\hline 3.933 & 1.817 & $\mathbf{- 5 . 5 0 7}$ & dependence & Discretionary accrual accounting \\
\hline 4.8594 & 2.1654 & 0.6417 & Independence & Non executive director Ratio \\
\hline 2.8215 & 1.6115 & 6.6430 & Independence & ownership Concentration ratio \\
\hline
\end{tabular}

As it is shown in the above table, the deviation results from criteria and the variables variances in companies are close to each other and are not much.

Before the investigation of hypothesis we investigate the presumptions regression model:

i. The investigation of being normality of reminders. In this case the "Kolmugrouf Smirnove" test has been used; one method for investigating the results of this test is drawing the diagrammatic reminders which have been mentioned below:

Table 3: normal plot of un standardized residual Normal Q-Q Plot or Unstandardized Residual

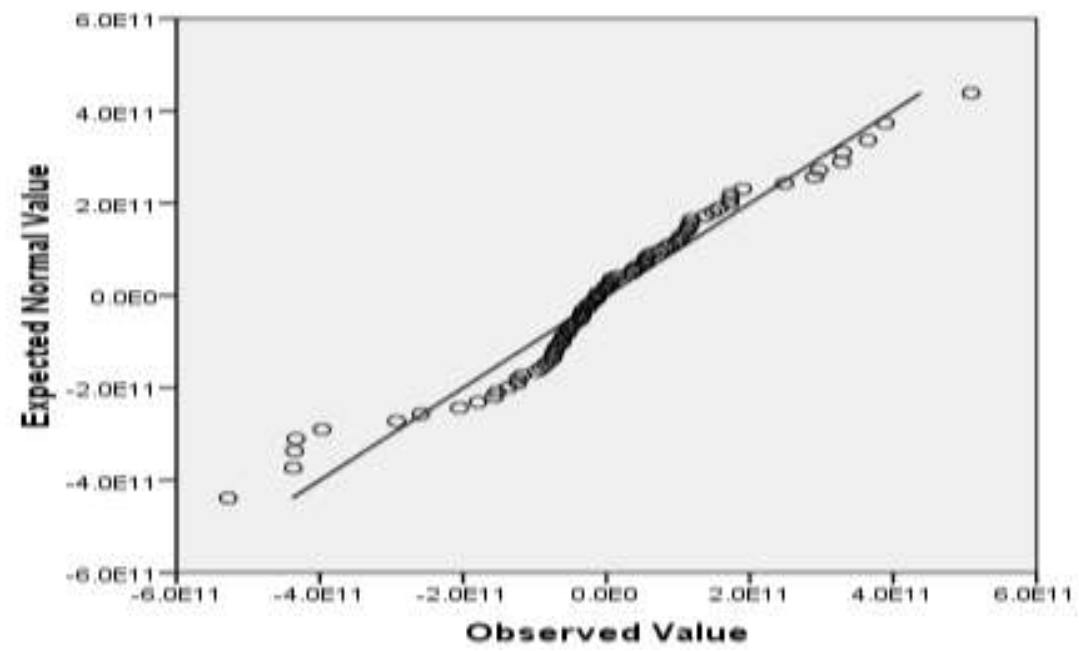


Moreover, the results of statistical hypothesis $\mathrm{H}_{0}$ based upon data normality, since $\mathrm{P}$-value is more than $\% 5$ the confirmation and the hypothesis confronting it has not been confirmed.
$\frac{\mathbf{N}}{178}$
$\frac{\text { Normal Paramet }}{.0000074}$
Kolomorov- Smirnov
$\underline{\text { Sign }}$
1.141
$\widehat{0.148}$

ii. The investigation of independence observation. In this test with the help of a Durbin-Watson dependant errors is assessed, or on the other hand, the investigation of whether the observed quantities have relationship with the other qualitative observations or not? If the hypothesis of the independent errors is not confirmed, the use of regression is impossible the results of this test have been show as below:

Table 4: consequence of Durbin-Watson test

\begin{tabular}{|l|l|l|l|l|l|}
\hline \multirow{2}{*}{ Model } & \multirow{2}{*}{$\mathrm{R}$} & Change Statistics & \multicolumn{2}{|l|}{ Durbin-Watson } \\
\cline { 3 - 6 } & & R Square Change & F Change & & \\
\hline 1 & $.099 \mathrm{a}$ & .010 & .855 & & 1.766 \\
\hline
\end{tabular}

As it is shown in the above table, the technical Durbin -Watson at normal level in, that is, more than 1.5 and less than 2.5. Thus we can conclude that the errors are dependant from each other.

iii. The conforming test of independent variables. For the investigation that whether independent variables have high correlation or not, the VIF has been used which its results show lack of correlation between independent variables with each other.

The investigation of the research has been complied considering Iran environmental situations as below:

\section{1-Research Hypothesis}

In the first hypothesis has been mentioned that there is a negative and meaningful relationship between discretionary accrual accounting items with none executive director. In this hypothesis, it is supposed that companies whose number of out-board director is more than in-board directors, the rate of discretionary accrual accounting items, is more too. Therefore, CEO have the motivation of manipulate financial figures. The results of the regression experiment have been mentioned as follow:

\begin{tabular}{|c|c|c|c|c|c|}
\hline \multirow{2}{*}{ Model } & \multirow{2}{*}{ R Square } & \multirow{2}{*}{ Adjusted R Square } & \multirow{2}{*}{ Std. Error of the Estimate } & & \\
\hline & & & & R Square Change & Sig. F \\
\hline 1 & .19 & 0.09 & $3.802 \mathrm{E} 11$ & 0.09 & 0.12 \\
\hline
\end{tabular}

As results are shown in the table above, sig F scale is more than the scale of acceptable error level (It means \%5). Therefore the hypothesis is not confirmed and the meaningful relationship between in-board and the discretionary accrual accounting items scale is not confirmed, as well.

The coefficient signal is positive and low which reveals the positive and direct relationship between them. The correlation intensity between them is on the basis of $\mathrm{R}^{2}$ coefficient, multiple $\% 9$.

Base on second hypothesis, there is a meaningful relationship and negative between ownership concentration and the discretionary accrual accounting items. On the basis of Iran corporate governance, companies shouldn't prefer the majority's to minority's interest and should not have priority. but the manager are usually chosen by the majority, thus the majority's profit protection has priority. We expect that this event changes in to reality, and the more is the portion distribution, the possibility of earnings manipulation is more, the results of the statistical experiment as follows:

\begin{tabular}{|l|l|l|l|l|l|}
\hline \multirow{2}{*}{ Model } & \multirow{2}{*}{ R Square } & Adjusted R Square & Std. Error of the Estimate & \multicolumn{3}{|c|}{} \\
\cline { 5 - 6 } & & & & R Square Change & Sig. F Change \\
\hline 1 & 0.75 & -0.67 & $2.036 \mathrm{E} 11$ & -0.67 & 0.032 \\
\hline
\end{tabular}


As the above table show ,sign $\mathrm{F}$ is less than alpha $\% 5$ therefore, the negative and significant relationship between ownership concentration and discretionary accrual accounting items is confirmed. It means, in companies which ownership dispersion is high, then possibility has earnings manipulation occur.

\section{2-Other Statistical Results}

One of the variables which are very important and significant in Iranian companies is the type of the company's ownership with respect to governmental and non-governmental. We expect that in private companies due to overhauling the competition concept and market and increasing the owner' wealth, the earnings manipulation and stakeholders' misleading often occurs or is weaker. More over the internal auditing because of its role over improvement of supervision on manager should have an active role, furthermore, this earning manipulation is more for misleading the stockholders and beneficiaries in companies due to financial problems who involved with financial stress. On the basis of Iran trade law such companies have loss of accumulation more than their capital, by dividing the companies into two groups bankrupt and un bankruptcy, it was obvious that in bankrupt companies the average of this standard is more and managers of these companies have more motivation for earning manipulation.

The variable size of the companies as an effective factor on motivation possibilities for earnings management in different researches in Iran, the size of the natural logarithm of sale corporations entered as control variable in research method. The total results haven't changed for none of the hypothesis but the relationships reinforced a lot as though it increased for ownership concentration 83 percent and for non executive directors 24 percent which express the meaningful effect of the variable. These results in brief show bellow:

\begin{tabular}{|l|l|l|l|l|l|l|}
\hline $\begin{array}{l}\text { Average } \\
\text { nonexecutive } \\
\text { directors } \\
\text { ratio }\end{array}$ & $\begin{array}{l}\text { Bankruptcy of } \\
\text { corporation }\end{array}$ & $\begin{array}{l}\text { Rank of } \\
\text { Concentration }\end{array}$ & $\begin{array}{l}\text { Mean of } \\
\text { earnings } \\
\text { management }\end{array}$ & $\begin{array}{l}\text { Don't have } \\
\text { internal } \\
\text { Auditor }\end{array}$ & $\begin{array}{l}\text { Have } \\
\text { internal } \\
\text { Auditor }\end{array}$ & Description \\
\hline 0.39 & 4 & 3.6534 & 2.2732 & 20 & 78 & $\begin{array}{l}\text { Private } \\
\text { Corporation }\end{array}$ \\
\hline 0.62 & 16 & 8.5429 & 5.8764 & 39 & 41 & $\begin{array}{l}\text { Government } \\
\text { Corporation }\end{array}$ \\
\hline & 20 & & & 59 & 119 & Total \\
\hline
\end{tabular}

\section{DISCUSSION AND CONCLUSION}

On the basis of theoretical framework research and also other carried out researches in Iran, it was supposed that by accomplishing the corporate governance in Iran, the supervision over managers' performance of companies has been improved decreasing or omission of discretionary accrual accounting or manipulate of the earnings by managers.

In first hypothesis, the relationship between out-board and earnings management has not been confirmed and there is a positive relationship. The existence of out-board is mostly for the protection of stockholder beneficiary in Iranian companies and for managers don't have the possibility of profit manipulation. This goal has not been confirmed in this hypothesis. Therefore managers manipulate earnings for achieve their goals . Their goals often are continues management on corporation and compensation and up price of shares corporation. Results revealed earnings management in governmental corporation is high as the private corporations .Further more mean of earnings management in private corporation is low ,rank of concentration of corporations is low too. Number of corporations are bankruptcy in private corporations is low thus weak financial corporation almost manipulate earnings and mean of earnings management in power financial corporation is lower than weak corporations .In contrary in governmental corporations bankruptcy is more and mean earnings management is more and ownership concentrations is more .corporation that manipulate earnings generally do not protect of internal auditors. As results shown, in private corporations non executive directors ratio is very low thus board of directors often full time and busy directors and managers cannot manipulate earnings.

In the second hypothesis, the relationship between ownership concentration and discretionary accrual accounting item has been confirmed. Their relationship is meaningful and negative. Thus ownership dispersion 
in corporation causes to managers for earnings manipulation. This is more in government ownership corporations to private corporations. If ownership of corporation is concentrate then managers for supervise by board and stockholders possibility cannot smoothing earnings. Results revealed that in corporations that concentrations ownership is high and do not internal auditors and nonexecutive directors is high , mean of earnings management is high too ,thus management can easily and without supervision manage earnings. More above, results shown that corporate that has high concentration ratio are high nonexecutive ratio and high earnings management ,thus managers with knowledge and cooperative with board of directors manipulate earnings.

In final base on results of research and investigate corporate governance law of Iran suggestion include:

i. TSE corporation do not ranking as corporate governance same other countries

ii. In almost, board of directors corporations do not have financial or accounting or economic technical membership thus decision board of directors almost without economical.

iii. .Number of nonexecutive directors is higher than executive directors in Iranian corporation ,thus managers can without supervision of board manipulate earnings

\section{REFERENCE}

1. Abdoli, M. R.(2010),"Capital Structure and Corporate Governance",Research paper ,Unpublished.

2. Agaiee,M. and Chalaki,P,(2010),"Relation of corporate Governance and Earning Management in TSE",Iranian accounting review, 2(35), 35.

3. Atmaja , L.Y.S, (2009), Governance mechanisms and firm value :The impact of ownership concentration and dividends, corporate governance : An international review , 17(6), 694-709.

4. Azar, A. and Momeni, M. (2007),"Statistics and Application on Management" ,Samt publication ,Tehran.

5. Al-Abbas ,M ,(2009)" Corporate Governance and Earnings Management : An Emperical Study of the Saudi Market, Journal of American Academy of Buisness , Cambrige,Sep, 15(1), 301.10.

6. Board accounting standard of iran,2009,"Accounting standards",,Official Auditing of Iran,Tehran.

7. Dechow, P., Sloan, R. and Sweeny, A. (1996), "Causes and Consequences of Earning Manipulation: An Analysis of FirmsSubject to Enforcement Actions by the SEC". ContemporaryAccounting Research, 13, 1-36.

8. Hasas,Y.(2009),"Effect of Board of Directores on Corporate Governance",Journal of Hesabdar, 21(174), 12-32.

9. Hasas,Y.(2008),"Effect of Corporate Governance on Earnings Management" ,quarterly study of accounting,4(17), 123-134.

10. Iqbal , Z. and Lewis , M.K , (2009), An Islamic perspective on governance ,Edward elgar publishing limited : Gloucestershire, 384pg.

11. Judge William,(2010), Corporate governance mechanisms throughout the world, Corporate governance : An International review , 18(3), 159-160.

12. Meca,E.G. and Ballesta,J.S, (2009), Corporate governance and earnings management : A metaanalysis, Corporate governance : An International review , 17 (5) , 594- 610.

13. Mehrazin ,A and Noravesh,I. AND nikomaram , H.(2008), "Assesment of Model of Accrual Accounting and Detection of Earnings Managements",Thesis of Doctorial Accounting,Sience and Research Branch of Islamic azad university,Tehran.

14. Midary ,A.(2006), "Relation Type of Corporate Governance and Economics Iran", Thesis of doctorial economic,Tehran.

15. Park, K., R. Park, and L. Hwang, 2005, Corporate governance and the distribution of shareholder wealth, Asia-Pacific Journal of Financial Studies 34, 149-188.

16. Piot ,c. and Janin ,R.(2007), External auditors , audit committees , and earnings management in France ,Europian accounting review, 16(2), 429.

17. Renders , A. and Gaeremynck ,A. and Sercu ,p, 2010, Corporate governance ratings and company performance : A cross- europian study, Corporate governance : An international review, 18(2).

18. Piot ,c. and Janin ,R.(2007)," External Auditors ,Audit committees,and Earnings Management in France ,Europian Accounting Review, 16(2), 429.

19. Roychowdhury, S., (2004). "Management of Earningthrough the Manipulation of Real Activities". Working Paper.University of Rochester, New York.

20. Roychowdhury, S., (2006). "Earnings Management through Real Activities Manipulation", Journal of Accounting andEconomics,42,335-370.

21. Sylvia,V.S.and Utama,s.(2008)," Type of Earnings Management and Effect of Ownership Structure ,Firm size, and Corporate -Governance Practices : Eidence frome Indonesia",The international journal of accounting, 43, 1-27. 
22. Teresa,M.Pergola et al ,(2009) " Effects of Corporate Governance and Board Equity Ownership on Earnings quality ,An Emperical study ",Available at www.Google.com

23. www.rdis.ir (include all of Iranian financial statements corporations in TSE )

24. Yazdanian,N.(2007) ,"Corporate Governance and Earnings Mmanagements",Iranian accounting review, 12(3), 29-42. 